\title{
Comparing Waste-to-Energy technologies by applying energy system analysis
}

\author{
Münster, Marie; Lund, Henrik
}

Published in:

Waste Management

Link to article, DOI:

10.1016/j.wasman.2009.07.001

Publication date:

2010

Document Version

Peer reviewed version

Link back to DTU Orbit

Citation (APA):

Münster, M., \& Lund, H. (2010). Comparing Waste-to-Energy technologies by applying energy system analysis. Waste Management, 30(7), 1251-1263. https://doi.org/10.1016/j.wasman.2009.07.001

\section{General rights}

Copyright and moral rights for the publications made accessible in the public portal are retained by the authors and/or other copyright owners and it is a condition of accessing publications that users recognise and abide by the legal requirements associated with these rights.

- Users may download and print one copy of any publication from the public portal for the purpose of private study or research.

- You may not further distribute the material or use it for any profit-making activity or commercial gain

- You may freely distribute the URL identifying the publication in the public portal

If you believe that this document breaches copyright please contact us providing details, and we will remove access to the work immediately and investigate your claim. 


\title{
Comparing Waste-to-Energy Technologies by applying Energy System Analysis
}

\author{
Marie Münster* and Henrik Lund \\ Department for Development and Planning \\ Aalborg University
}

Fibigerstraede 13, DK-9220 Aalborg Oest

\section{POSTPRINT}

Article published in:

Waste Management, Vol. 30, No. 7, 2010, p. 1251-1263.

DOI 10.1016/i.wasman.2009.07.001

*E-mail: marie.mynster@risoe.dk. Tel: +45 46775166. Fax: +45 46775199 


\section{Abstract}

Even when policies of waste prevention, re-use and recycling are prioritised a fraction of waste will still be left which can be used for energy recovery. This article asks the question: How to utilise waste for energy in the best way seen from an energy system perspective? Eight different Wasteto-Energy technologies are compared with a focus on fuel efficiency, $\mathrm{CO}_{2}$ reductions and costs. The comparison is carried out by conducting detailed energy system analyses of the present as well as a potential future Danish energy system with a large share of combined heat and power as well as wind power. The study shows potential of using waste for the production of transport fuels. Biogas and thermal gasification technologies are hence interesting alternatives to waste incineration and it is recommended to support the use of biogas based on manure and organic waste. It is also recommended to support research into gasification of waste without the addition of coal and biomass. Together the two solutions may contribute to alternate use of one third of the waste which is currently incinerated. The remaining fractions should still be incinerated with priority to combined heat and power plants with high electric efficiency.

Key words: Waste-to-Energy, energy system analysis, biogas, thermal gasification, biofuel, CHP 


\section{Introduction}

How to use waste for energy in an optimal way now and in the future is a highly topical issue. Currently in Europe, governments and local authorities must comply with the existing waste management hierarchy when developing waste policy. The five steps of the hierarchy are:

1. Waste prevention (preferred option)

2. Re-use

3. Recycling

4. Recovery (including energy recovery)

5. Safe disposal (as a last resort).

New European legislation adopted on 20th October 2008 considers energyefficient waste incineration a recovery operation as opposed to the disposal of waste (European Commission 2005).

Even if the waste hierarchy is strictly followed there may still be a fraction of waste left which cannot be used for other purposes than energy recovery or disposal. At the moment, different uses of waste for energy production are in focus in the EU for a number of reasons:

- Waste resources are increasing and waste treatment capacities are becoming insufficient.

- EU legislation demands a change in the current treatment of waste, which at present is mainly disposed at landfill sites. The amount of biodegradable waste deposited at landfills in 2014 must not exceed $35 \%$ of the total amount of biodegradable waste produced in 1995 (Council Of The European Union 1999). Furthermore, the disposal of certain types of waste, such as combustible waste or untreated organic waste, is illegal in some member states, e.g. Denmark, Sweden and Germany.

- The use of waste for energy production can contribute to achieving the $20 \%$ renewable energy goal and the $20 \%$ reduction of $\mathrm{CO}_{2}$ emissions agreed upon at the European level (Commission Of The European Communities 2008).

When aiming at using waste for energy production the question arises: which type of energy recovery is the optimal? According to which criteria?

Environmentally or seen from an energy systems perspective?

A range of new Waste-to-Energy (WtE) technologies are promising in terms of offering electricity, heat and transport fuels. These technologies have the potential for increasing electric efficiency, substituting transport fuels and storing waste fractions and fuel. They will thus contribute to an increased flexibility in the energy system compared to the current Danish practice of waste incineration with a high constant production of heat.

Particularly in societies with a large combined heat and power (CHP) production, in which electricity production is connected to heat demand, and with a large share of fluctuating energy sources, such as wind power, it is 
important to ensure that the production meets the demand at any given time. In order to analyse this, a dynamic model of the energy production and consumption must be made with hour-by-hour representation over a year. As CHP waste incineration is constant and produces a high percentage of heat, it may be interesting to look at more flexible alternatives which may facilitate integration of a larger share of wind power.

Environmental issues are in general analysed with a different focus than energy resource issues. The prioritisation between waste treatment options can be facilitated by a wide range of tools with different focus on economic and environmental impacts as well as impacts on society (Fatta \& Moll 2003; Finnveden et al. 2007a; Morrissey \& Browne 2004).

Energy system analysis (ESA) is used to assess the impact of particularly changes in energy production on e.g. national energy systems. This is an aspect which other assessment methods fail to address substantially. ESA focuses on one step of the life cycle (energy conversion), with simulation of all the interacting energy technologies, The cheapest energy production seen from the point of view of energy producers (including taxes) or society (excluding taxes) is found based on investment costs, operation and maintenance costs and fuel costs. $\mathrm{CO}_{2}$ quota costs are often included, but further externalities are often omitted. The focus on environment is normally limited to $\mathrm{CO}_{2}$ emissions and possibly also methane, sulphur and NOxes. The results of ESA's can be used directly to prioritise between technologies according to an energy system perspective focusing on e.g. costs, fuel efficiency or percentage of renewable energy. $\mathrm{CO}_{2}$ emissions from energy conversion represent the major part of the impact on global warming and ESA can hence be used as a parameter for decision-making seen from a climate perspective. The results can also be fed into LCA's if it is wished to prioritise from a broader and more detailed environmental perspective including the remaining parts of the life cycle. Assumptions regarding energy production is in many cases decisive for the outcome of the LCA's as shown by Ekvall (Ekvall 1999) and more recently in an article regarding marginal energy production by Mathiesen, Münster and Fruergaard (Mathiesen 2008). Furthermore, ESA can also contribute with results to other types of analysis focusing more on economy or the societal effects, such as cost benefit analysis (CBA) or multi criteria decision analysis (MCDA) (Morrissey \& Browne 2004).

Up to now a range of CBA's have been performed, particularly comparing incineration with landfilling (Dijkgraaf \& Vollebergh 2004; Eshet et al. 2005; Moutavtchi et al. 2008). A large number of LCA's have also been performed on waste management options (Baky \& Eriksson 2003; Cherubini et al. 2008; Eriksson et al. 2007; Finnveden et al. 2007b; Finnveden 1999; Kirkeby et al. 2006). and in the European Thematic Strategy on prevention and recycling of waste greater emphasis is now placed on life cycle thinking when evaluating waste management options (European Commission 2005). In order to include the aspect of flexibility when prioritising between different WtE technologies it is, however, necessary to use a model which simulates the dynamic properties of the energy system. This is possible when conducting ESA in hourly simulations. Some ESA models operate without hour-by-hour simulations and use for example load duration curves instead or other 
simplifications with regard to distribution in time (Cosmi et al. 2000; Holmgren \& Henning 2004; Knutsson et al. 2006; Ljunggren Soderman 2003; Luoranen \& Horttanainen 2008; Sahlin et al. 2004). This, however, does not make it possible to include the benefits of increased flexibility in the system analysis.

In most of the different types of analyses presented above, waste incineration is compared with non-energy waste treatment (Cosmi et al. 2000; Eshet et al. 2005; Holmgren \& Henning 2004; Ljunggren Soderman 2003; Luoranen \& Horttanainen 2008; Sahlin et al. 2004; Salvia et al. 2002) or with other fuel alternatives (Eriksson et al. 2007). The analyses show that, from a general environmental point of view, incineration is better than disposal at landfills, but worse than recycling. However, although inconsistencies exist in the CBA's resulting in differing conclusions, in general the studies conclude that incineration is more costly than landfilling (Dijkgraaf \& Vollebergh 2004; Eshet et al. 2005). Furthermore, in some cases and for some waste fractions incineration may be preferred to recycling (Holmgren \& Henning 2004; Ljunggren Soderman 2003). When incineration is compared with other WtE alternatives, the most common alternative is the production of biogas, as shown in a number of LCAs (Baky \& Eriksson 2003; Cherubini et al. 2008; Kirkeby et al. 2006). Here, the conclusions are unclear. Under some circumstances, the environmental consequences of biogas production used for CHP are comparable to those related to incineration (Baky \& Eriksson 2003; Kirkeby et al. 2006) but combined with dedicated residual derived fuel (RDF) combustion, biogas production may have lower environmental impact (Cherubini et al. 2008).

The existing analyses have not encompassed the influence of increased flexibility in energy systems with large shares of wind power. Furthermore, the $\mathrm{WtE}$ technologies have not been analysed in the context of future energy systems. Finally, few technologies are compared and only established technologies. In order to assess if it is feasible to prioritise research, development and demonstration of new technologies such as waste gasification or waste-to-biofuel technologies, it is however important to analyse the technologies although data regarding costs and efficiencies may be less certain.

In this article, ESA with hour-by-hour simulations of energy demands, fluctuating renewable energy sources and fluctuating electricity prices is used to compare a number of technological alternatives using waste for energy production. In 2008 Münster and Lund performed another energy system analysis of WtE technologies (Münster \& Lund 2008), but with fewer technologies, without trade of electricity with neighbouring countries, and only in the current energy system with less wind power. Encompassing these features facilitates an explorative approach as defined by Borjeson et. al. (Borjeson et al. 2006) as opposed to the more normative approach of the former article. The result of this study showed that the largest $\mathrm{CO}_{2}$ reduction was found with a manure-based biogas CHP alternative and the cheapest $\mathrm{CO}_{2}$ reduction was achieved with a syngas transport alternative including cogasification with coal. The results in the present article conclude that this alternative is feasible only if the co-gasification is omitted. This change in 
results is due to the improvements which have been added to the ESA model used. These improvements are described in the methodology section. In order to assess whether the technologies in question will function as planned or will obstruct the development of a desired future, they are analysed both in the current energy system as well as in a future energy system with $100 \%$ renewable energy. Hereby it becomes possible to recommend actions with regards to research in technologies. Positive results may also indicate that investments in infrastructure and built up of expertise will not be in vain. Furthermore, full $\mathrm{CO}_{2}$ reduction potentials of the various technologies are established by applying the full resource potentials of today. For further documentation and results see report on "Energy Systems Analysis of Waste-to-Energy Technologies using EnergyPLAN" (Münster 2008).

\section{Waste-to-Energy Technologies}

The Waste-to-Energy technologies compared in this article are listed in Table 1. The technologies are selected with the aim of representing a wide spectrum of possible alternatives, including thermo-chemical, bio-chemical and chemical conversion processes. The technologies have different outputs and characteristics in terms of flexibility making it possible to analyse different types of technologies' influence on the energy system. The technologies to some extent utilise different waste fractions. All technologies are commercial apart from Syngas and Bio-ethanol, which are still at the developmental stage and only being implemented at pilot plants or in demonstration plants. Data regarding these technologies are therefore the most uncertain and consequently sensitivity analyses have been performed for them on both efficiencies and investment costs. 


\begin{tabular}{|c|c|}
\hline Technology & Description \\
\hline $\begin{array}{l}\text { New waste } \\
\text { incineration }\end{array}$ & $\begin{array}{l}\text { CHP waste incineration with efficiencies of a new waste incineration plant. The technology is } \\
\text { commercial. The waste fraction must be used continuously. The plant is placed in a larger city area } \\
\text { with CHP. }\end{array}$ \\
\hline $\begin{array}{l}\text { Co- } \\
\text { combustion }\end{array}$ & $\begin{array}{l}\text { Residual derived fuel (RDF) is co-combusted with coal in a coal-fired power plant. The technology is at } \\
\text { full-scale demonstration stage. RDF can be stored. The plant is placed in a larger city area with CHP. }\end{array}$ \\
\hline $\begin{array}{l}\text { Dedicated } \\
\text { RDF }\end{array}$ & $\begin{array}{l}\text { RDF is burnt in a dedicated CHP plant. The technology is commercial. The plant is placed in a larger } \\
\text { city area with CHP. }\end{array}$ \\
\hline Biogas CHP & $\begin{array}{l}\text { Biogas from anaerobic digestion of organic household waste is used for CHP. The waste fraction must } \\
\text { be used continuously. In the Biogas+ alternative, the use of organic household waste is assumed to } \\
\text { facilitate the use of manure. The fibre fraction from the manure is burnt in a CHP plant. The } \\
\text { technology is commercial. The plant is placed in a smaller town area with CHP. }\end{array}$ \\
\hline $\begin{array}{l}\text { Biogas } \\
\text { Transport }\end{array}$ & $\begin{array}{l}\text { Biogas from anaerobic digestion of organic household waste is upgraded and used for transport in } \\
\text { natural gas vehicles. In the Biogas+ alternative, the use of organic household waste is assumed to } \\
\text { facilitate the use of manure. The fibre fraction from the manure is burnt in a CHP plant. The } \\
\text { technology is commercial. The plant is placed in a smaller town area with CHP. }\end{array}$ \\
\hline Syngas & $\begin{array}{l}\text { Municipal waste is liquidised and undergoes thermal gasification. The resulting syngas can be } \\
\text { converted to biopetrol or used for CHP. The technology is at developmental stage. The waste fraction } \\
\text { must be used continuously. In the Syngas+ alternative, it is assumed that the gasification of waste } \\
\text { requires the co-gasification of coal in an entrained flow gasifier ( } 75 \% \text { of energy). The plant is placed in } \\
\text { a larger city area with CHP. }\end{array}$ \\
\hline Biodiesel & $\begin{array}{l}\text { Animal fat, formerly used for industrial heat production, is converted to biodiesel in a trans- } \\
\text { esterification process. The animal fat can be stored. The technology is commercial. The plant is placed } \\
\text { in a smaller town area with CHP. }\end{array}$ \\
\hline Bioethanol & $\begin{array}{l}\text { Straw, grass and paper waste first undergoes pre-treatment and hydrolysis. Secondly, bioethanol is } \\
\text { produced for transport through fermentation and thirdly biogas is produced through anaerobic } \\
\text { digestion along with biofuel and hydrogen and used for CHP. The waste fractions can be stored. The } \\
\text { technology is at developmental stage. The plant is placed in a smaller town area with CHP. }\end{array}$ \\
\hline
\end{tabular}

It is chosen to include immature technologies as the technologies show great perspective in terms of conversion of waste to transport fuel, overall efficiency and flexibility. The specific technology design illustrates Danish projects, but similar projects are being developed worldwide. As predictions regarding efficiencies and investments costs tend to be optimistic for technologies under development the recommendations regarding these technologies can only be either 1) not to support further research in case the technologies are not competitive with current well proven technologies or 2) in case the results are positive, then to further investigate the matter and support further research in the technology.

Table 2 shows the efficiencies and the investment and operation and maintenance costs assumed for the technical alternatives in years 2006 and 2050. Bioethanol has the highest investment costs per PJ input in 2006. Waste incineration, RDF in 2006 and Syngas are at the same level. Cocombustion is by far the cheapest alternative in 2006, as only the extra cost of co-firing with RDF in an existing coal-fired power plant is taken into account. In 2050, Co-combustion of RDF and biomass is assumed to carry the proportional costs of a large-scale biomass steam turbine. In general, data has been found for plants of similar sizes to the required and from there, the investment costs have been adjusted linearly in order to correspond to the required input capacity. 
With regard to the investment costs for 2050, the first five alternatives on the list have been assigned the prices of 2020-2030, as given in the Technology Data for Electricity and Heat Generating Plants from the Danish Energy Authority et. al. 2005. Syngas investment costs have been kept at the same level, as the prices were already future prices with expectations of decreases in costs and increases in efficiencies. Biodiesel investment costs have also been maintained, as biodiesel is a fairly mature technology which is not expected to change significantly in the future. Finally, investment costs for bioethanol have been changed to costs from the Well-To-Wheels Report by EUCAR et. al. 2007, as these represent an estimate of future costs and a significant reduction in costs compared to the costs of 2006. 
Table 2 Efficiencies and Investment, Operation and Maintenance Costs of WtE technologies in 2006 and 2050

\begin{tabular}{|c|c|c|c|c|c|c|c|c|}
\hline & & $\begin{array}{l}\text { Conversi } \\
\text { on } \\
\text { efficienc } \\
\text { y }(\%)\end{array}$ & $\begin{array}{l}\text { Electrici } \\
\text { ty } \\
\text { efficien } \\
\text { cy (\%) }\end{array}$ & $\begin{array}{l}\text { Heat } \\
\text { efficie } \\
\text { ncy } \\
(\%)\end{array}$ & $\begin{array}{l}\text { Transport } \\
\text { fuel } \\
\text { efficiency } \\
(\%)\end{array}$ & $\begin{array}{l}\text { Investm } \\
\text { ent } \\
\text { (MEUR/ } \\
\text { PJ) }\end{array}$ & $\begin{array}{l}\text { O\&M } \\
\text { (\% of } \\
\text { inv.) }\end{array}$ & Reference \\
\hline $\begin{array}{l}\text { New waste } \\
\text { incineration }\end{array}$ & 2006 & & 19,5 & 65,4 & & 52.2 & 7 & $\begin{array}{l}\text { (Danish Energy } \\
\text { Authority et al. 2005) }\end{array}$ \\
\hline \multirow[t]{2}{*}{$\begin{array}{l}\text { Co- } \\
\text { combustion }\end{array}$} & 2006 & & $34,4^{1}$ & $26,0^{1}$ & & $1.7^{2}$ & $10^{2}$ & $\begin{array}{l}\text { (DONG Energy } \\
\text { 2007b) }{ }^{1} /(\text { Danish Energy } \\
\text { Authority et al. 2005) }\end{array}$ \\
\hline & 2050 & & 48,5 & 41,5 & & 22.2 & 4 & $\begin{array}{l}\text { (Danish Energy } \\
\text { Authority et al. 2005) }\end{array}$ \\
\hline \multirow[t]{2}{*}{ Biogas CHP } & 2006 & $40,9^{1}$ & $42,0^{2}$ & $50,0^{2}$ & & $\begin{array}{l}5.9^{2} / 18.3^{2} \\
a\end{array}$ & $7^{2}$ & $\begin{array}{l}\text { (Christensen et al. } \\
2003)^{1}+(\text { Danish Energy } \\
\text { Authority et al. } \\
2005)^{1} /(\text { Danish Energy } \\
\text { Authority et al. 2005) }\end{array}$ \\
\hline & 2050 & $40,9^{1}$ & $46,0^{2}$ & $50,0^{2}$ & & $\begin{array}{l}4.7^{2} / 14.8^{2} \\
a\end{array}$ & $7^{2}$ & $\begin{array}{l}\text { (Christensen et al. } \\
2003)^{1}+(\text { Danish Energy } \\
\text { Authority et al. } \\
2005)^{1} /(\text { Danish Energy } \\
\text { Authority et al. 2005) }\end{array}$ \\
\hline \multirow[t]{2}{*}{ Syngas } & 2006 & $77,8^{1}$ & $47,0^{1}$ & $45,0^{1}$ & $70^{1 b}$ & $50.9^{2}$ & $4^{2}$ & $\begin{array}{l}\text { (DONG Energy } \\
2007 a)^{1} /(\text { EUCAR et al. } \\
2007)^{2}\end{array}$ \\
\hline & 2050 & $77,8^{1}$ & $47,0^{1}$ & $45,0^{1}$ & $70^{1 \mathrm{~b}}$ & $50.9^{2}$ & $4^{2}$ & $\begin{array}{l}\text { (DONG Energy } \\
2007 a)^{1}(\text { EUCAR et al. } \\
2007)^{22}\end{array}$ \\
\hline \multirow[t]{2}{*}{ Biodiesel } & 2006 & $90,4^{1}$ & & & $100^{1}$ & $13.9^{2}$ & $1^{2}$ & $\begin{array}{l}\text { (Jensen et al. } \\
\text { 2007) }{ }^{1} /(\text { Andreasen } \\
2007)^{2}\end{array}$ \\
\hline & 2050 & $90,4^{1}$ & & & $100^{1}$ & $13.9^{2}$ & $1^{2}$ & $\begin{array}{l}\text { (Jensen et al. } \\
\text { 2007) }{ }^{1} /(\text { Andreasen } \\
2007)^{2}\end{array}$ \\
\hline \multirow[t]{2}{*}{ Bioethanol } & 2006 & $76,0^{1}$ & $42,0^{2}$ & $50,0^{2}$ & $46^{1 b}$ & $65.0^{1}$ & $10^{1}$ & $\begin{array}{l}(\text { BioGasol 2007) })^{1} / \\
(\text { Danish Energy } \\
\text { Authority et al. 2005) }\end{array}$ \\
\hline & 2050 & $76,0^{1}$ & $46,0^{2}$ & $50,0^{2}$ & $46^{1 b}$ & $29.0^{3}$ & $10^{3}$ & $\begin{array}{l}(\text { BioGasol } \\
2007)^{1} /(\text { Danish Energy } \\
\text { Authority et al. } \\
2005)^{2} /(\text { EUCAR et al. } \\
2007)^{3}\end{array}$ \\
\hline
\end{tabular}

a) Biogas Plus alternatives

b) Percentage of converted fuel used as transportation fuel. The rest is used as fuel for CHP. 


\section{Waste Resources}

Fruergaard has identified the resource potential of the various fractions used by the Waste-to-Energy plants (Fruergaard 2008). Table 3 is based on the findings of Fruergaard and illustrates the full potential. Furthermore, the table illustrates which type of waste resources can be used in which plants. It is worth noticing that, in all cases, the majority of the waste which is currently incinerated must still be incinerated, as only minor fractions can be sorted out and used in the different technologies.

The total potentials identified are listed in the left column. The other columns illustrate the percentage of the resource in question, which can be utilised in the respective technologies. The potentials of paper, plastic and organic waste are the potentials which can be sorted out from the mixed waste. If these waste resources are not used for other WtE technologies, they are incinerated. The amounts of incinerated waste are shown in parenthesis. It can be seen that, although some fractions can be sorted out and used for other purposes than waste incineration, significant amounts of waste must still be incinerated.

Animal fat is currently used for industrial heating. The potential of straw is not utilised today. In the modelling, it is burnt in a biomass CHP plant together with 5.4 PJ of wood, which is not used currently, either. In this way, the same resource is used for each alternative apart from the Biogas + and the Bioethanol alternatives, which assume that the construction of such type of plant facilitates the utilisation of unused resources (industrial waste, sludge, manure and grass). The largest resource which is made available for energy production in WtE plants is manure. It generates almost the same amount of energy as the waste fraction which is currently incinerated. Furthermore, the Syngas+ alternative requires the addition of coal to run the process. In the future, it may be possible to co-gasify with biomass. 
Table 3 Potential waste resources

\begin{tabular}{|c|c|c|c|c|c|c|c|c|}
\hline $\begin{array}{l}\text { Total } \\
\text { (PJ) }\end{array}$ & $\begin{array}{l}\text { New } \\
\text { Incine- } \\
\text { ration (\%) }\end{array}$ & $\begin{array}{l}\text { Co- } \\
\text { combustion } \\
\text { (\%) }\end{array}$ & $\begin{array}{l}\text { RDF } \\
\text { (\%) }\end{array}$ & $\begin{array}{l}\text { Biogas } \\
\text { CHP (\%) }\end{array}$ & $\begin{array}{l}\text { Biogas } \\
\text { Transport } \\
(\%)\end{array}$ & $\begin{array}{l}\text { Syngas }^{a} \\
\text { (\%) }\end{array}$ & $\begin{array}{l}\text { Bio- } \\
\text { diesel } \\
(\%)\end{array}$ & $\begin{array}{l}\text { Bio- } \\
\text { ethanol } \\
\text { (\%) }\end{array}$ \\
\hline
\end{tabular}

\begin{tabular}{|c|c|c|c|c|c|c|c|c|c|}
\hline \multicolumn{10}{|c|}{ Resources used for waste incineration } \\
\hline Paper & $(6.0)$ & 0 & 100 & 100 & 0 & 0 & 100 & 0 & 100 \\
\hline Plastic & $(1.0)$ & 0 & 100 & 100 & 0 & 0 & 100 & 0 & 0 \\
\hline Org waste & (3.4) & 0 & 0 & 0 & 41 & 41 & 100 & 0 & 0 \\
\hline $\begin{array}{l}\text { Mixed } \\
\text { waste }\end{array}$ & 37.4 & $28 /(72)$ & (81) & (81) & (96) & (96) & (72) & (100) & (84) \\
\hline
\end{tabular}

Resources used for industrial heating

\begin{tabular}{|c|c|c|c|c|c|c|c|c|c|}
\hline Animal fat & 3.2 & 0 & 0 & 0 & 0 & 0 & 0 & 100 & 0 \\
\hline \multicolumn{10}{|c|}{ Resources currently not used for energy } \\
\hline Straw & 12.2 & 0 & 0 & 0 & 0 & 0 & 0 & 0 & 100 \\
\hline $\begin{array}{l}\text { Industrial } \\
\text { waste }\end{array}$ & 2.0 & 0 & 0 & 0 & 100 & 100 & 0 & 0 & 0 \\
\hline Sludge & 5.1 & 0 & 0 & 0 & 100 & 100 & 0 & 0 & 0 \\
\hline Manure & 32.5 & 0 & 0 & 0 & 100 & 100 & 0 & 0 & 0 \\
\hline Grass & 1.4 & 0 & 0 & 0 & 0 & 0 & 0 & 0 & 100 \\
\hline
\end{tabular}

a) For the Syngas+ alternative 31.2 PJ coal is used for the gasification process

Table 3 reflects the amounts used for the scenario utilising the full waste resource. In the scenarios of 2006 and 2050 in which a marginal amount of the waste is redistributed, the fractions are taken from the current use, such as incineration, and added to the respective technologies. In the Biogas+ alternatives, manure is added and, in Syngas+, coal is added in 2006 and biomass in 2050. For simplicity, only the straw and paper fractions are used in the Bioethanol alternative. This scenario hence illustrates a situation in which both straw and paper are already being used, and the negative consequences of removing the resources from their current use are included in the analysis.

\section{Energy System Analysis Model}

The energy system analysis was made by use of the EnergyPLAN model, which is developed at Aalborg University. The EnergyPLAN model is a computer model designed for energy systems analysis. The main purpose of the model is to assist the design of national or regional energy planning strategies on the basis of technical and economic analyses of the consequences of implementing different energy systems and investments. The model can be downloaded free of charge on www.energyplan.eu. On the webpage a mathematical representation of the model as well as documentation can be found. Examples can be seen of analyses made by use of the model, including a number of case studies by Lund and others (Lund \& Munster 2006; Lund 2007b) as well as comparisons of results with other models as in Lund et al. 2007 (Lund et al. 2007). A brief description of the 
model is presented below. For more thorough explanations, please consult (Lund 2007a; Lund \& Münster 2003).

The EnergyPLAN model is a deterministic input/output model. General inputs are demands, renewable energy sources, energy station capacities, costs, and a number of optional different regulation strategies emphasising import/export and excess electricity production. Outputs are energy balances and resulting annual productions, fuel consumption, $\mathrm{CO}_{2}$ emissions, import/export of electricity, and total costs including income from the exchange of electricity. A schematic overview of the model can be seen in Figure 1.

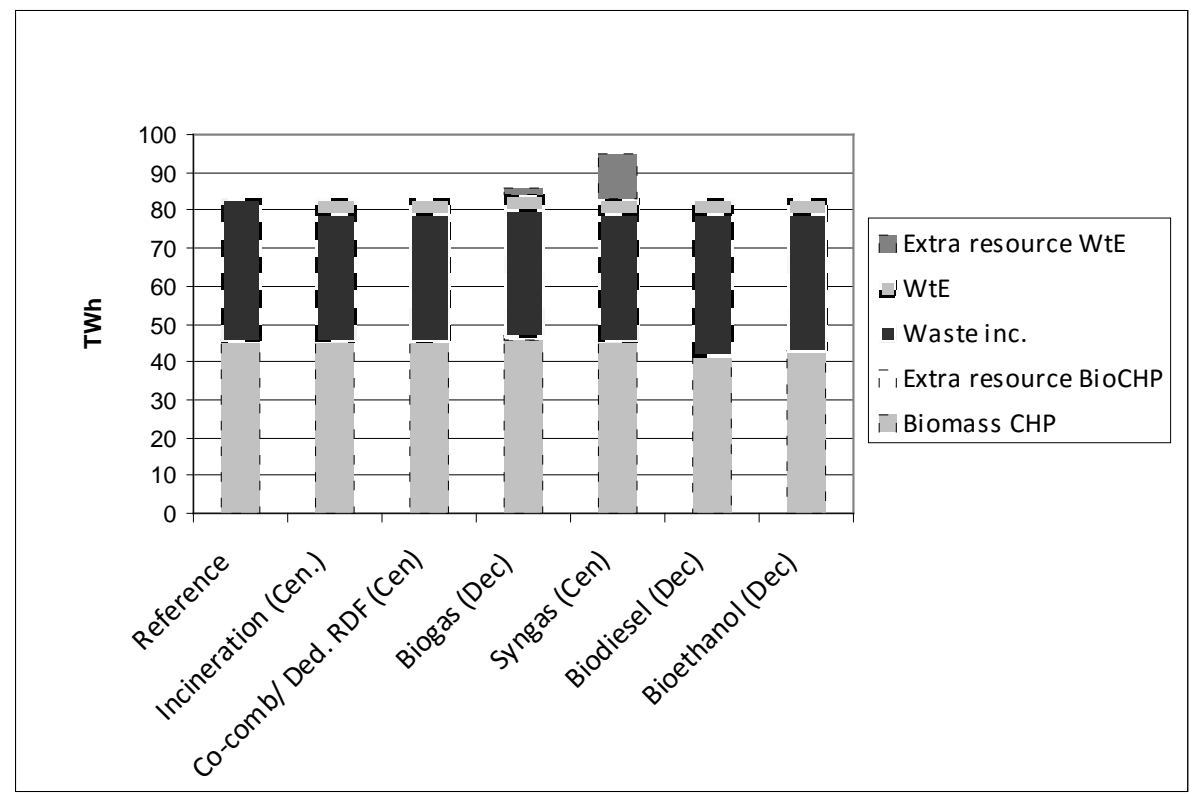

Figure 1 Resource use for the WtE alternatives per TWh of changed use of waste (and adding 2 PJ manure in the Biogas+ alternatives and 12 PJ coal in the Syngas+ alternative)

The fluctuating demands, production and prices are fed into the model as hourly distributions over a year. The input data are regulated by a number of strategies illustrating e.g. how CHP plants are operated on the market and how critical excess electricity production is reduced.

The model is an aggregated model where Denmark is divided into three types of areas:

- DH areas, which are supplied by district heating plants only

- Dec CHP areas, which are smaller town areas supplied by CHP plants and boilers

- Cen CHP areas, which are larger city areas supplied by CHP plants, condensing power plants and boilers

The model can simulate both a closed system with no electricity exchange and an open system. It is interesting to simulate a closed system in order to evaluate whether the energy system can utilise the energy produced at a given hour and thus ensure an efficient system. This can facilitate the trade of electricity at times when the Danish actors wish to do so - and not when they are forced to do it. Likewise, the model can perform either a technical 
optimisation with the aim of improving the fuel efficiency of the system or a market optimisation with the objective of improving the financial output of the individual plants.

EnergyPLAN includes a large number of traditional technologies, such as power stations, CHP and boilers, as well as energy conversion and technologies used in renewable energy systems, such as heat pumps, electrolysers, and heat, electricity and hydrogen storage technologies including Compressed Air Energy Storage (CAES) (Lund et al. 2009). The model can also include a number of alternative vehicles, for instance sophisticated technologies such as V2G (Vehicle to grid) in which vehicles supply the electric grid (Lund \& Lempton 2008). Moreover, the model includes various renewable energy sources, such as solar thermal and photovoltaic (PV), wind, wave and hydro power.

The model encompasses the whole national or regional energy system including heat and electricity supplies as well as the transport and industrial sectors. With regard to electricity supply, the model emphasises the analysis of different regulation strategies with a focus on the interaction between CHP and fluctuating renewable energy sources.

As part of this study, the model has been expanded in order to include Syngas technologies in the regulation strategies. The Syngas unit is defined in the model as a unit which converts waste, coal and biomass into biopetrol, electricty and heat. The Syngas plant utilises waste which cannot be stored. Coal and/or biomass may be added to facilitate the energy conversion process work.

The Syngas plant can choose to produce either primarily biofuel (Operation mode 1) or primarily CHP (Operation mode 2). The plant is assumed to be able to operate linearly between the two modules.

The technical regulation is based on the following principle: If the total fuel consumption of the system can be reduced by replacing electricity at a power plant and heat in the district heating system instead of producing petrol, the operation will be changed. The market economic regulation is based on the following principle: If the marginal cost of producing electricity is lower than the market price (in competition with all other units), the Syngas unit will change to module 2 . In the analyses of this article, the Syngas plant mainly runs in mode 1. A mathematical representation of the module is included in Appendix A.

\section{Danish Reference Energy System}

In this section, the assumptions and principles of the reference energy system are described. To a large extent, the same reference energy system is used as in the Heat Plan Denmark project (Dyrelund et al. 2008). The reference energy system is based on the latest base forecast of the energy system of the Danish Energy Authority from January 2008 (Danish Energy Authority 2008b).

The reference energy system has been compared to the corrected base forecast of the Danish Energy Authority (Danish Energy Authority 2008b) and the Energy Statistics 2006 (Danish Energy Authority 2007). The most notable difference involves the import and the export of electricity, which are significantly higher in the Energy Statistics 2006 than in the model. However, 
as the fuel consumptions match well, the model is still assumed to represent a valid picture of reality.

When reconstructing the base forecast of the Danish Energy Authority, assumptions regarding the development of fuel prices are based on the latest description of assumptions for socio-economic analysis in the energy sector of the Danish Energy Authority (Danish Energy Authority 2008a). Fuel prices and waste resource prices can be seen in Table 4 . An average electricity price of 362 DKK1/MWh, as found on the NordPool in 2006, has been used (Energinet.dk 2008). Furthermore, a CO2 price of $160 \mathrm{DKK} / \mathrm{t}$ has been used to match the consumption of fuels and net electricity export in 2006 (Danish Energy Authority 2007).

Table 4 Fuel prices and waste resource prices

\begin{tabular}{lll}
\hline Fuel & DKK/GJ & Reference \\
\hline Coal & 15,8 & (Danish Energy Authority 2008a) \\
\hline Fuel oil & 54,0 & (Danish Energy Authority 2008a) \\
\hline Diesel & 96,5 & (Danish Energy Authority 2008a) \\
\hline Petrol & 102,7 & (Danish Energy Authority 2008a) \\
\hline Natural gas & 48,0 & (Danish Energy Authority 2008a) \\
\hline Straw & 22,9 & (Danish Energy Authority 2008a) \\
\hline Waste resource & & \\
\hline Mixed incinerable waste & -20 & (RenoSam 2006) \\
\hline RDF & 39 & (Greiner 2007) \\
\hline Organic household waste & -112 & (Billund Municipality 2008; Solum 2008) \\
\hline Manure & -10 & (Münster 2008a) \\
\hline Organic industrial waste & 5 & (Kristensen 2008; Münster 2008a) \\
\hline Sludge & -1024 & (Kristensen 2008; Solum 2008) \\
\hline Animal fat & 114 & (DAKA 2008) \\
\hline Grass & -7 & (BOFA 2008; Oestdeponi 2008; Renordvest 2008) \\
\hline
\end{tabular}

In Table 4, negative prices illustrate money received for treating waste. For conventional fuels, a world market exists and, for straw, a Danish market helps establishing the prices of the fuels with a fair amount of certainty. The same cannot be said about waste resources, which have prices ranging from positive to negative, depending on energy content, ease of handling, harmful substances, etc. In the analysis, the income from the current treatment of the waste fraction (mostly incineration) is subtracted and the income or expense of the fraction in the alternative $\mathrm{WtE}$ technology is added. The positive costs of the waste fractions - e.g. RDF - represent the increased cost of transportation as well as pre-treatment of the waste in order to achieve the required size and quality or alternatively of purchasing the equivalent. The alternatives have been modelled in the energy system of 2006 with economic optimisation focusing on the improvement of the financial output

${ }^{1}$ The rate of exchange is 7.5 DKK to 1 EUR 
of the individual plants, including electricity trade with neighbouring countries.

The reference energy system for 2050 is based on the 2050 vision of The Danish Society of Engineers' Energy Plan, which is a system with $100 \%$ renewable energy (Lund \& Mathiesen 2008). It is the official goal of the Danish government to achieve an energy system with $100 \%$ renewable energy. It is impossible to forecast how future energy systems will be, but the energy system used for this analysis represents one possible combination of technologies, which can supply Denmark with electricity, heat and transport fuels with a massive utilisation of both wind power and biomass. For simplicity, it is assumed that the waste for incineration stabilises at the current level and the reference energy system is therefore the same as the 2050 vision of The Danish Society of Engineers' Energy Plan. The same amount of waste is added as in the reference for 2006 and with the same distribution, but utilised with higher efficiency as in Heat Plan Denmark (Dyrelund et al. 2008).

The biomass price is expected to increase to 53,7 DKK/GJ in 2025 (EA Energy Analysis 2008). For simplicity, it is assumed that the price remains at this level until 2050. The increase in biomass price is $16 \%$ and waste fractions have increased by the same percentage.

The average electricity price in 2025 has been analysed in the energy system analysis model Balmorel and found to be approximately $550 \mathrm{DKK} / \mathrm{MWh}$, with coal power plants being the prime marginal electricity producing technology (Bregnbaek 2008). The price is used for 2050 under the assumption that the price remains at that level, and that Denmark trades electricity with countries which still have coal condensing plants, although Denmark is supplied $100 \%$ by renewable energy. $\mathrm{A} \mathrm{CO}_{2}$ price of $225 \mathrm{DKK} / \mathrm{t}$ has been applied, which is the $\mathrm{CO}_{2}$ quota price expected by the Danish Energy Authority from 2013 (Danish Energy Authority 2008b). The alternatives have been modelled in the energy system of 2050 . The system is modelled with electricity trade with neighbouring countries and technical optimisation aiming at improving the fuel efficiency of the system. An economic optimisation of the system would require input of taxation and estimations made about taxation in 2050 are too uncertain.

\section{Results}

Three scenarios have been analysed and the results are presented in the sections below:

- Marginal change in today's energy system

- Marginal change in a $100 \%$ renewable energy system

- Use of full resource potential in today's energy system 


\subsection{Marginal change in today's energy system}

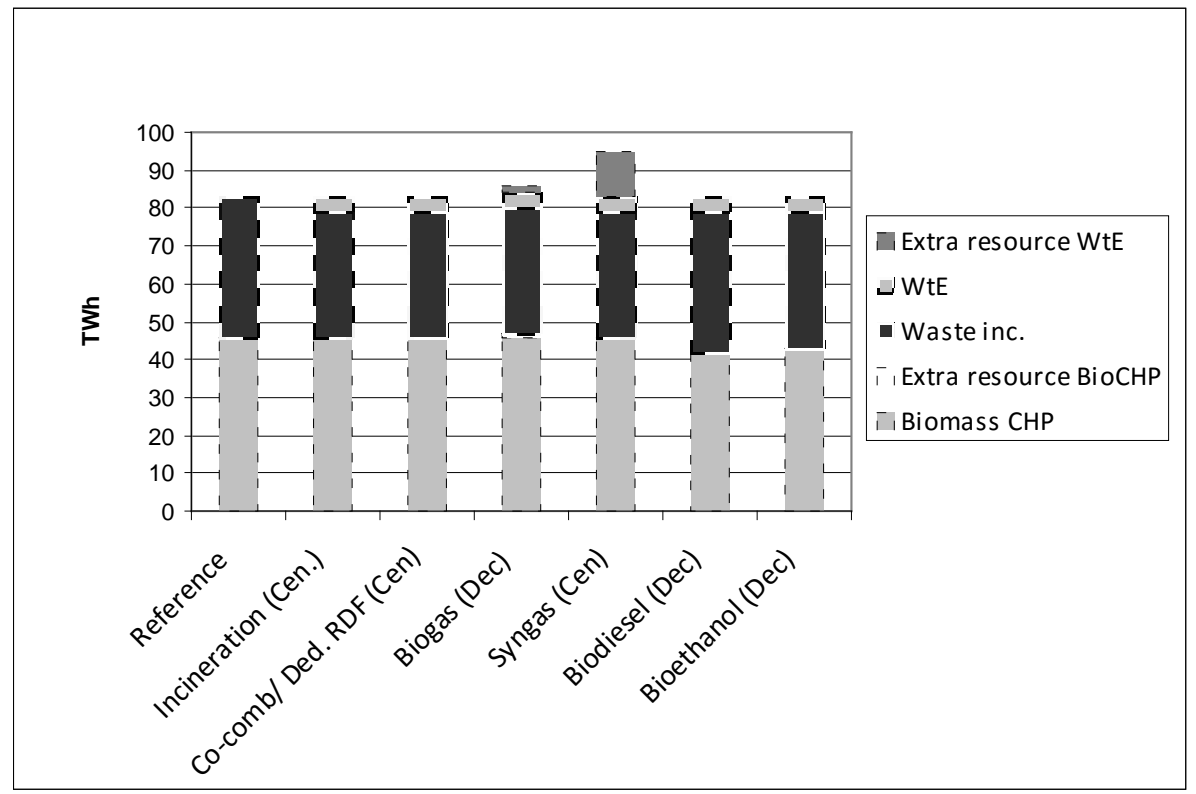

Figure 2 Resource use for the WtE alternatives per TWh of changed use of waste (and adding 2 PJ manure in the Biogas+ alternatives and 12 PJ coal in the Syngas+alternative)

The resources used when redistributing a marginal amount of waste ( $1 \mathrm{TWh}$ ) are illustrated in Figure 2. In some alternatives, the waste which is currently used in waste incineration plants is redistributed to other WtE plants and, in other alternatives, the use of waste in biomass plants changes (e.g. Biodiesel and Bioethanol). In the Biogas+ alternatives, manure is added (2 PJ) and the fibre fraction from the manure is added to biomass CHP. In Figure 2 the Syngas+ alternative, coal is added (12 PJ).

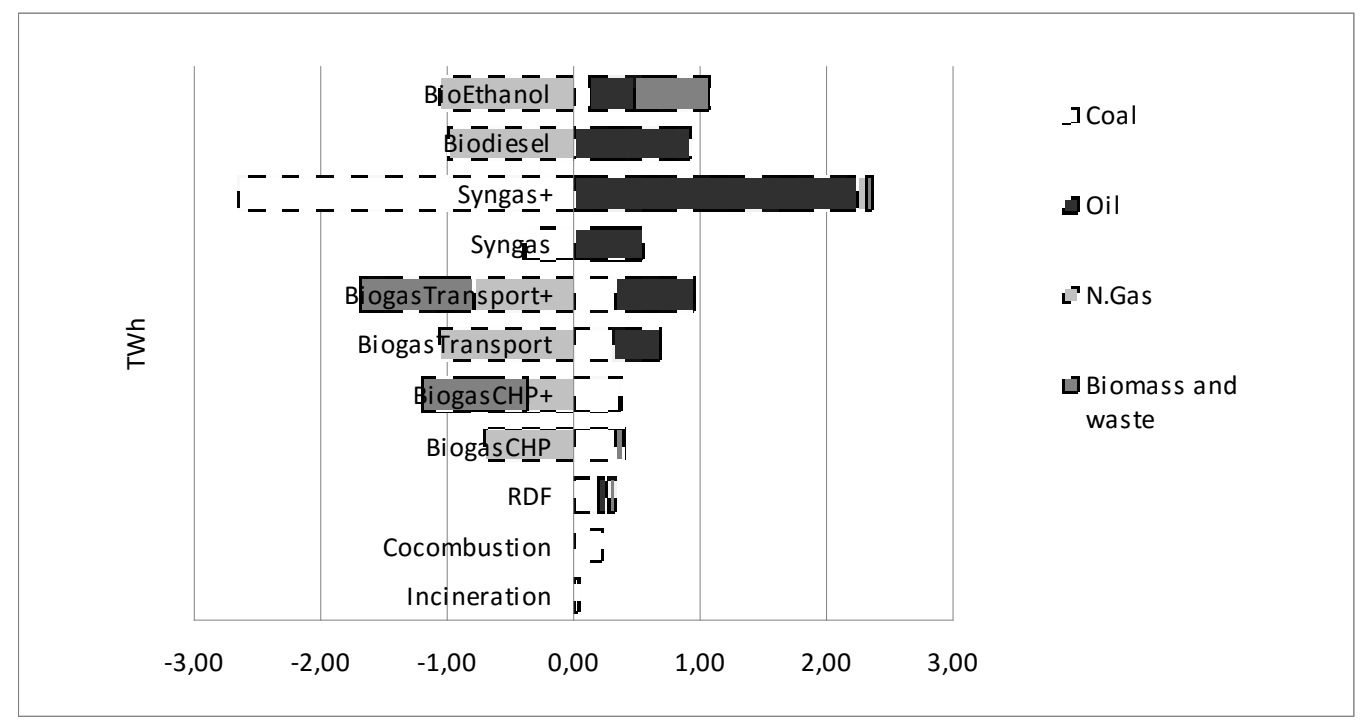

Figure 3 Total substituted fuel for all WtE technologies per TWh of changed use of waste (and adding 2 PJ manure in the Biogas+alternatives and 12 PJ coal in the Syngas+alternative)

Figure 3 illustrates the substituted fuel or decreased consumption as positive figures and the induced fuel or increased consumption as negative figures. 
Results from the technical alternatives are subtracted from the reference energy system.

When changing the use of waste, the benefit of adding waste is reduced by the disadvantage of removing a similar amount. The alternatives producing transport fuels substitute oil. The largest oil substitution is achieved in the Biodiesel alternative. The CHP alternatives mainly substitute coal. The largest substitution of coal is achieved in the BiogasCHP alternative.

Natural gas is the main fuel in the smaller town areas and coal is the main fuel in the larger city areas. The alternatives placed in smaller town areas (Biogas, Biodisel and Bioethanol) therefore result in increased consumption of natural gas in order to substitute the amount of waste removed from waste incineration plants. Apart from Syngas, the alternatives placed in larger city areas (Incineration, Co-combustion, RDF and Syngas) result in a minor net substitution of coal.

The increased biomass use in the Biogas+ alternatives represents the manure added, and the difference in the coal consumption of the Syngas and the Syngas+ alternative illustrates the coal needed for co-gasification. In the Bioethanol alternative, biomass is substituted, as it is here assumed that straw is moved from biomass CHP to the bioethanol plant.

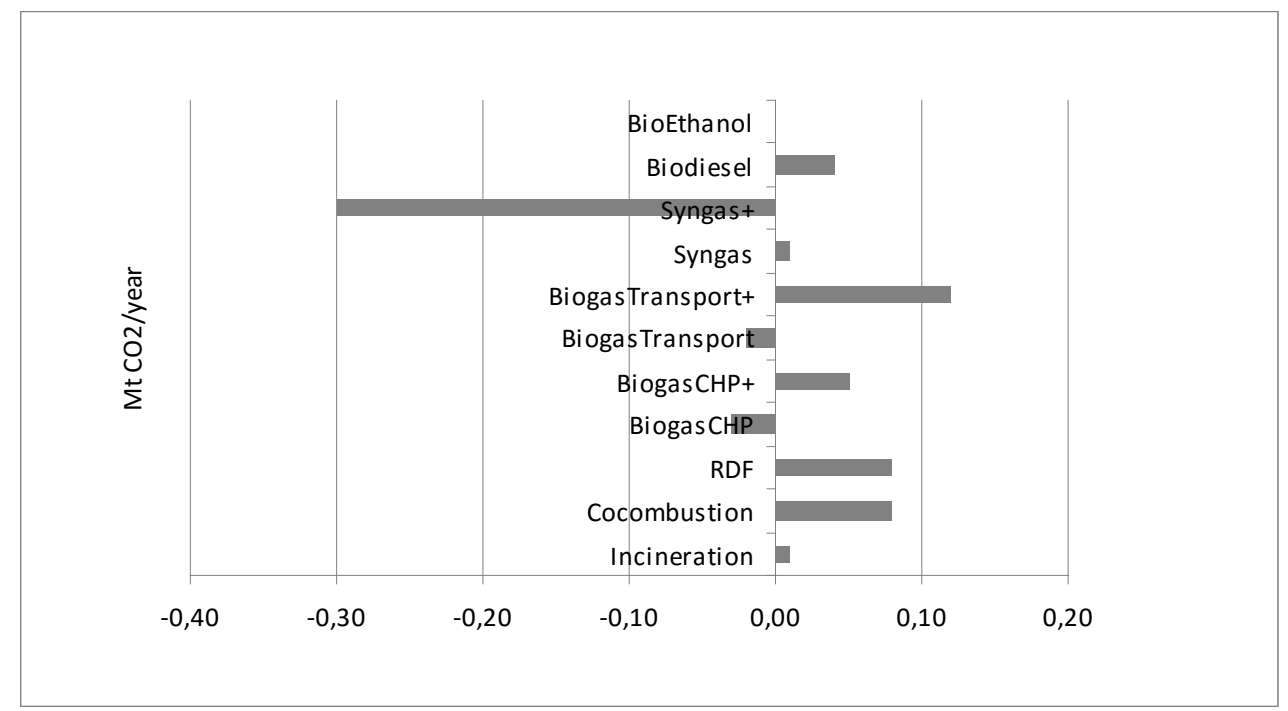

Figure 4 Total CO2 emission reduction per TWh of changed use of waste (and adding 2 PJ manure in the Biogas+ alternatives and 12 PJ coal in the Syngas+alternative).

Figure 4 illustrates the differences in $\mathrm{CO}_{2}$ emissions of the Danish energy system between the reference energy system and the various alternatives. In terms of total $\mathrm{CO}_{2}$ emissions including emissions related to export, in most cases, a reduction takes place compared to the reference energy system. Only the Syngas+, the Biogas CHP and the Biogas Transport alternatives emit more than the reference energy system. The alternatives with least $\mathrm{CO}_{2}$ emissions are the BiogasTransport+ and the Co-combustion and RDF alternatives. 
If only the emissions from domestic consumption 2 are taken into account, the picture changes slightly. In this case, Syngas+ is by far the alternative which substitutes most CO2 followed by Biogas Transport+ and Cocombustion. The fact that Syngas+ changes from being one of the worst to the best alternative depending on the perspective illustrates the importance of identifying the correct marginal electricity producing unit when attempting to isolate the $\mathrm{CO} 2$ emissions related to domestic electricity consumption. Assuming that the marginal is always coal-fired power plants is a crude simplification. The best way to identify the marginal electricity producing unit in Denmark is to apply an energy model which incorporates the entire Nordic electricity market.

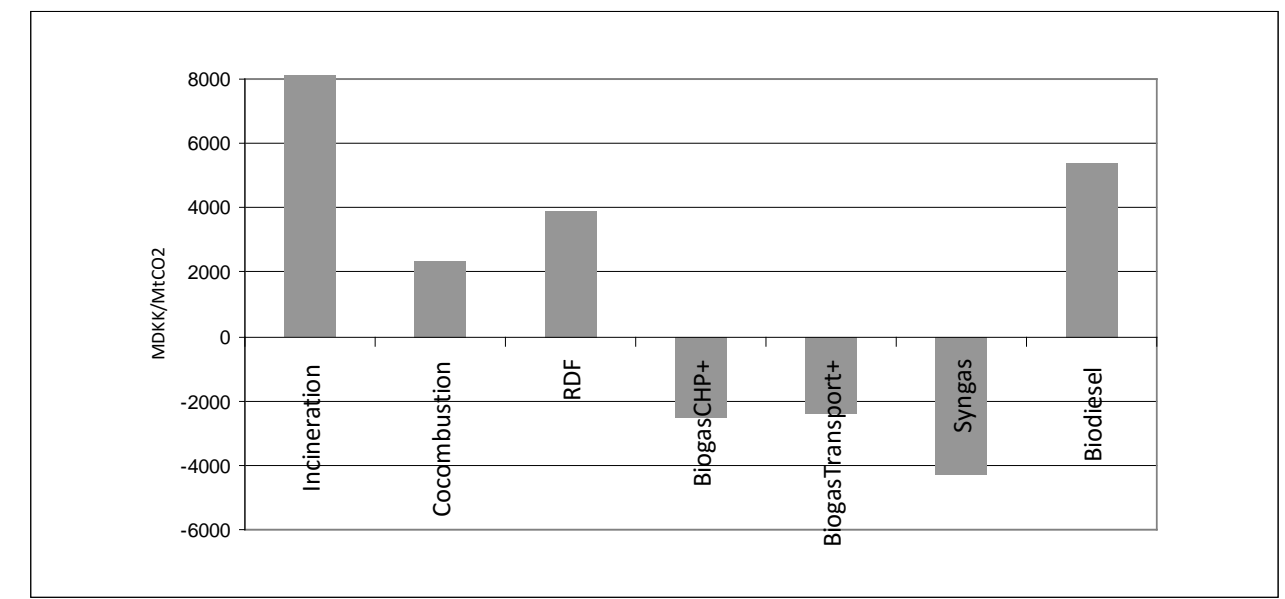

Figure 5 CO2 reduction cost per TWh changed use of waste. Incineration is almost 20000 MDKK/Mt CO2 and is cut off.

Figure 5 illustrates the $\mathrm{CO}_{2}$ reduction costs of the alternatives which result in reduced $\mathrm{CO}_{2}$ emissions. From the figure, it can be seen that the Biogas+ and Syngas alternatives represent savings compared to today's system and Incineration is the most expensive alternative in terms of $\mathrm{CO}_{2}$ reduction at almost $20000 \mathrm{DKK} / \mathrm{t} \mathrm{CO}_{2}$. The Syngas alternative represents the largest negative $\mathrm{CO}_{2}$ reduction price as a small saving in costs is divided by a very small $\mathrm{CO}_{2}$ reduction. By comparison, BiogasTransport+ provides both the largest savings in costs and in $\mathrm{CO}_{2}$ emissions. BiogasTransport+ has more than twice as high savings in costs as BiogasCHP+ due to lower costs for conventional fuels and it has more than 6 times as high savings in costs as Syngas. Here, the lower fuel costs of Syngas are outweighed by substantially lower costs for waste resources of BiogasTransport+.

\subsection{Marginal change in a $100 \%$ renewable energy system}

The choice of technologies in which to invest and conduct research has impacts on the technology use for decades ahead. In order to avoid investing in energy technologies which will obstruct a desired future, the same technologies have been analysed in a future energy system with $100 \%$

\footnotetext{
2 The CO2 emissions from domestic consumption are found by assuming that condensing coal-fired power plants (electric efficiency of 40\%) are the marginal power producing plants.
} 
renewable energy. The results are compared to a reference with no use of waste for energy.

As the system relies $100 \%$ on renewable energy (RE), the only $\mathrm{CO}_{2}$ emissions from energy conversion stems from the fossil part of the waste utilised. This fraction is the same in all alternatives apart from the reference system in which no waste is used. As biomass will be a limited resource in a 100\% RE system, the focus on reducing $\mathrm{CO}_{2}$ emissions changes to a focus on reducing biomass consumption.

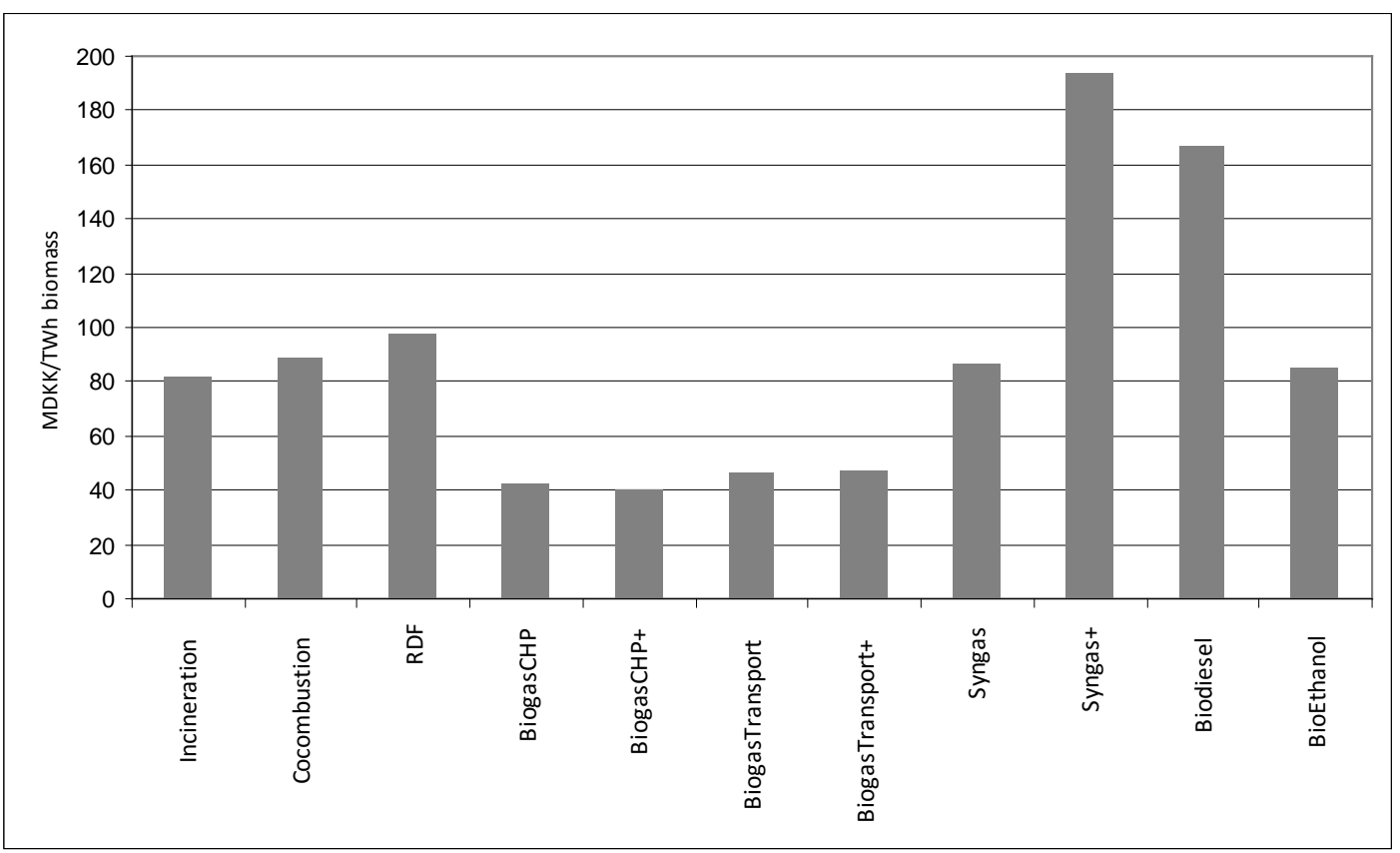

Figure 6 Biomass reduction cost per TWh changed use of waste in 2050

When comparing Figure 6 with the $\mathrm{CO}_{2}$ reduction costs in 2006, the biogas solutions are once again among the best alternatives with the biomass reduction cost of BiogasCHP+ of $40 \mathrm{DKK} / \mathrm{TWh}$ or $11 \mathrm{DKK} / \mathrm{GJ}$ biomass. The Incineration, Co-combustion, RDF, Syngas and Bioethanol alternatives follow with $\mathrm{CO}_{2}$ reduction costs between 82 and $98 \mathrm{DKK} / \mathrm{TWh}$. The highest reduction costs are achieved in the Biodiesel and Syngas+ alternatives. Compared to a biomass cost of $54 \mathrm{DKK} / \mathrm{GJ}$, even the highest biomass reduction cost of $194 \mathrm{DKK} / \mathrm{TWh}$ is, however, feasible.

It can be concluded that if we prioritise the Biogas+ and the Syngas alternatives today, the choice will not hamper the achievement of a $100 \%$ renewable energy system. Furthermore, investments in research, development and demonstration as well as in supporting infrastructure may not be in vain. 


\subsection{Use of full resource potential in today's energy system}

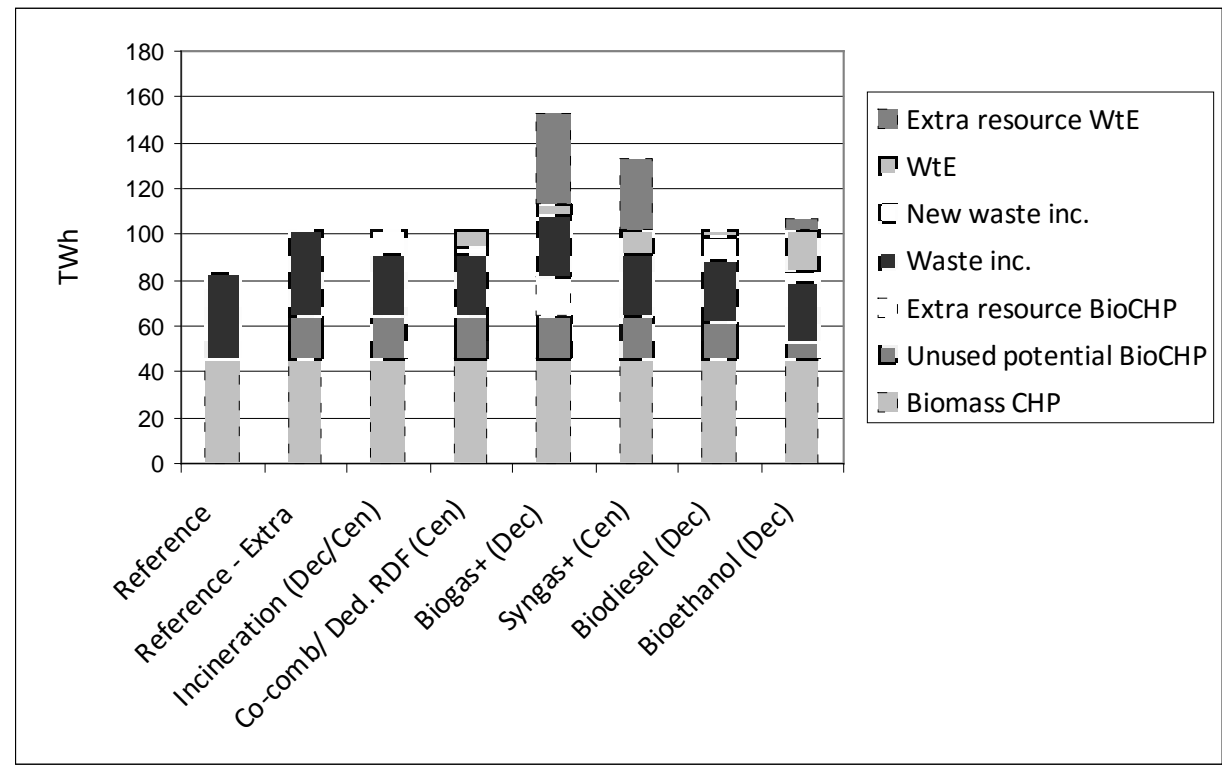

Figure 7 Resource use for the WtE alternatives when using full resource potential in 2006

To assess the maximum possible reduction of $\mathrm{CO}_{2}$, the full resource potential is analysed. The resource use is illustrated in Figure 7. In the Biogas+ alternatives, the full potential of organic household waste, manure, organic industrial waste and sludge is used. In the Syngas+ alternative, coal is included and, in the Syngas alternative, it is not. 10 PJ waste is used in new waste incineration plants (35\% in the smaller towns and 65\% in larger city areas) unless it is used in the other conversion plants.

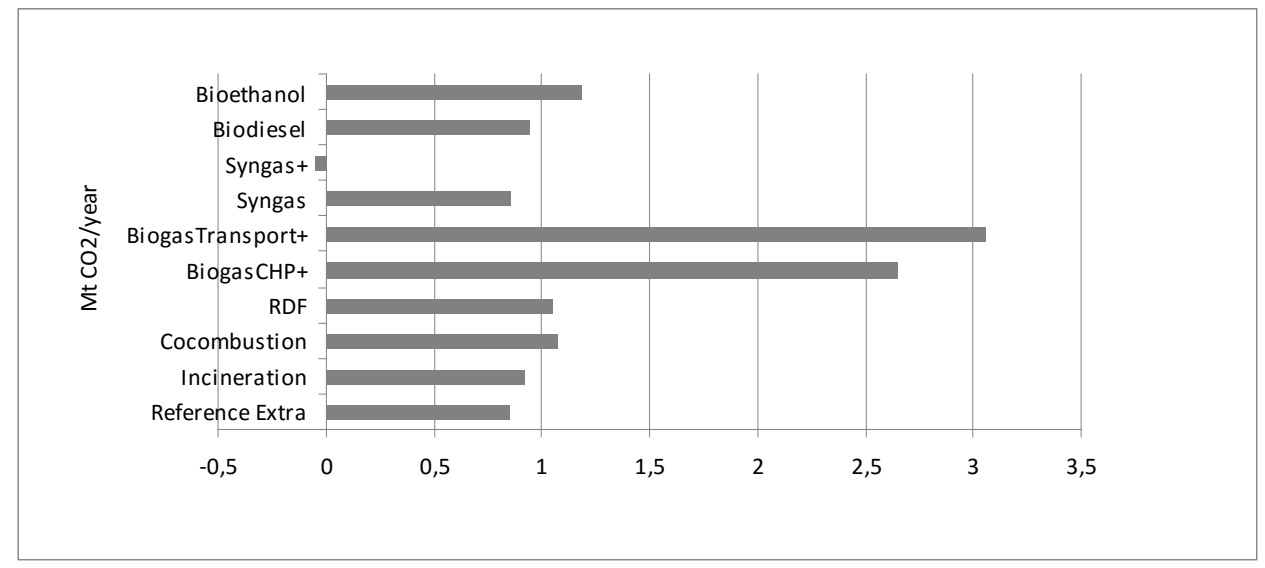

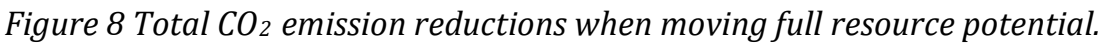

Due to the variations in the resource amounts used, greater variations are found regarding $\mathrm{CO}_{2}$ emissions, as illustrated in Figure 8.

The maximum potential reduction in $\mathrm{CO}_{2}$ emissions from one technology is $3.06 \mathrm{Mt} /$ year, which can be achieved with the BiogasTransport+ alternative. The BiogasCHP+ alternative performs almost as well. The Syngas+ is marginally worse than the reference system, when looking at total $\mathrm{CO}_{2}$ emissions including emissions from export, and as good as the BiogasTransport+ alternative (2.9 Mt/ year) if only looking at emissions from domestic consumption. The Syngas alternative can provide a total $\mathrm{CO}_{2}$ 
reduction of $0.86 \mathrm{Mt} / \mathrm{year}$. As the technologies utilise different resources, even further emission reductions can be achieved by combining several of the technologies.

\subsection{Sensitivity analysis}

To determine to which extent the analysis is robust or sensitive, sensitivity analyses have been performed of the marginal change in today's energy system. The parameters analysed are:

- Waste resource prices (+/- $30 \mathrm{DKK} / \mathrm{GJ})$

- Investment costs (Syngas $+130 \%$, Bioethanol -55\%)

- Efficiencies (Syngas -22\%, Bioethanol -41\%, CoComb -1\% Coal Power Plant and $-3 \%$ remaining waste incineration)

- Fuel prices $(+20 \%)$

- $\mathrm{CO}_{2}$ quota prices (+40\%)

- Interest rate $(6 \%)$

Waste resource prices are very uncertain as, in many cases, no larger market is established for the fractions and prices depend on local conditions and treatment capacities. To assess the sensitivity of the results to the costs of the waste fractions, an analysis has been made in which an amount of $30 \mathrm{DKK} / \mathrm{GJ}$ has first been added and later subtracted from the price of the waste fraction used for the respective technologies. For RDF the decrease results in a price of $9 \mathrm{DKK} / \mathrm{GJ}$, which represents a negative cost combined with a moderate expense for pre-treatment and extra transport.

As the investment costs of the non-commercial WtE technologies are associated with great uncertainty, the investment costs of the Syngas and the Bioethanol solutions have been held up against investment costs from other sources, which results in an increase in the Syngas (Nexant 2006) and a decrease in the Bioethanol investment cost (EUCAR et al. 2007).

As the efficiencies of the technologies under development are also highly uncertain, sensitivity analyses have also been performed for these. For Syngas the efficiency of liquefaction has been reduced in accordance with Goudiraan et. al (Goudriaan et al. 2000) and the efficiency of gasification has been slightly raised in accordance with the European Well-to-Wheel study (EUCAR et al. 2007) resulting in a combined efficiency decrease of $22 \%$. For BioEthanol the efficiency of fuel production has been raised to $45 \%$ at the cost of producing biofuel for CHP, in accordance with production of bioethanol from straw in the Well-to-Wheel study (EUCAR et al. 2007). A sensitivity analysis has also been introduced for Cocombustion. Here the efficiency of the coal power plants is reduced by $1 \%$ point due to use of electricity for pre-treatment (Møller et al. 2008) and assuming that the lower heating value of the remaining waste fraction drops $4 \mathrm{MJ} / \mathrm{kg}$, The efficiencies of the remaining waste incineration plants decrease with $3 \%$ points, and the CB value is decreased by 0.02 (Hulgaard 2009).

Fuel cost has been increased by $20 \%$ to a level around 119 USD/bbl in order to test the sensitivity of the results to this parameter (Danish Energy Authority 2008b). The $\mathrm{CO}_{2}$ quota price has been increased from 160 to 225 $\mathrm{DKK} / \mathrm{t} \mathrm{CO} 2$. Finally, the sensitivity of changing the interest rate from $3 \%$ to $6 \%$ has been examined. 


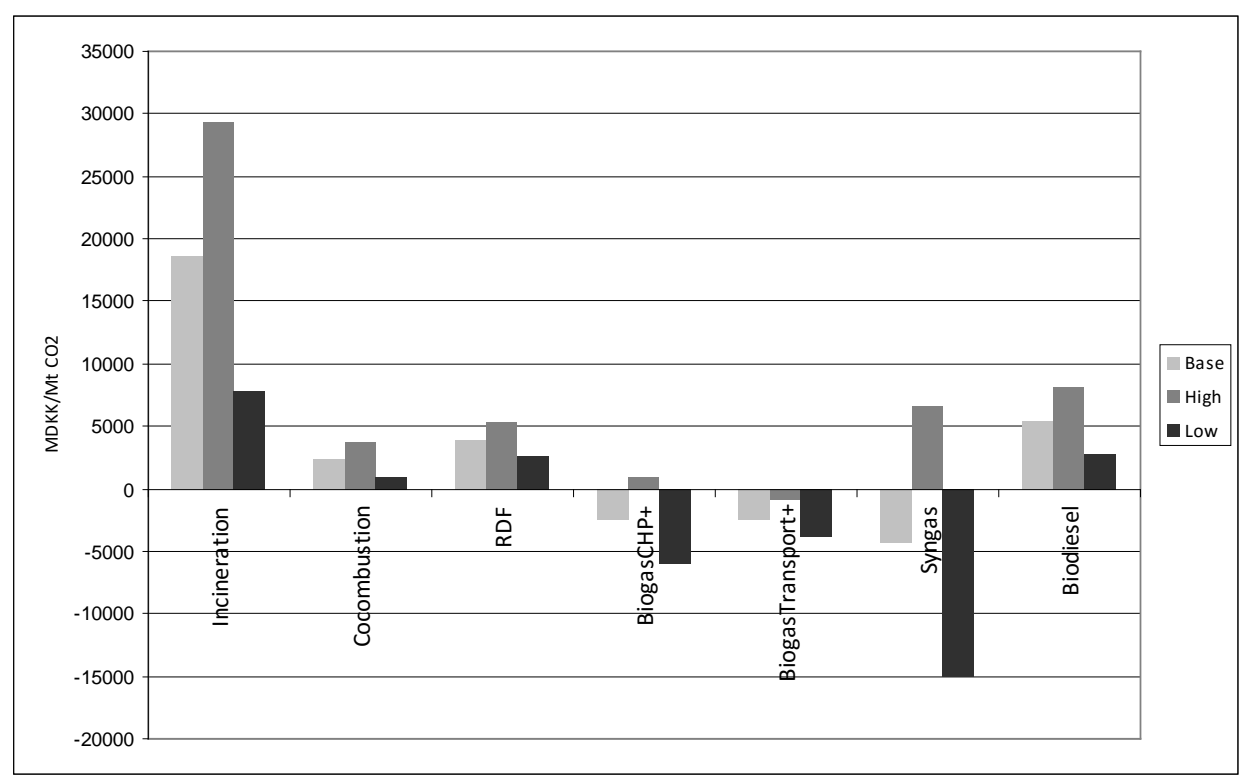

Figure $9 \mathrm{CO}_{2}$ reduction prices in situations with high (+30 DKK/GJ) and with low waste resource prices (-30 DKK/GJ) compared to the reference prices.

As can be seen in Figure 9, the results are highly sensitive to waste resource prices. Particularly the Syngas and Incineration alternatives vary considerably with variations of almost $22500 \mathrm{DKK} / \mathrm{t} \mathrm{CO} 2$ in reduction prices. Syngas varies between highly positive and highly negative $\mathrm{CO}_{2}$ reduction costs. BiogasCHP also varies between positive and negative $\mathrm{CO}_{2}$ reduction costs although with lower variation. BiogasTransport+ has low variations and has constant negative $\mathrm{CO}_{2}$ reduction prices as the only alternative. The results are also highly sensitive to investment costs. The Syngas alternative changes from a negative reduction cost of -4000 to a positive of $+14000 \mathrm{DKK} / \mathrm{t} \mathrm{CO}_{2}$ and the increase of costs from the reference system to the BioEthanol alternative changes from $430 \mathrm{MDKK} /$ year to only 270 MDKK/year.

The decreased overall efficiency of the Syngas plant now results in increased $\mathrm{CO}_{2}$ emissions as less oil is displaced and more coal is consumed. The same is the case for Syngas+ which now results in an even greater increase in $\mathrm{CO}_{2}$ emissions. BioEthanol on the other hand now results in a decrease in $\mathrm{CO}_{2}$ emissions. Although less coal is displaced for CHP, more oil is displaced. The $\mathrm{CO}_{2}$ reduction cost is however almost 2.5 times the reduction cost of Incineration. With regards to co-combustion the decrease in efficiency now results in a net zero decrease in $\mathrm{CO}_{2}$ emissions illustrating high sensitivity to relatively minor changes in efficiency.

Furthermore, with increased fuel prices, $\mathrm{CO}_{2}$ quota prices and interest rate, the Co-combustion and RDF alternatives result in increased $\mathrm{CO}_{2}$ emissions compared to the reference energy system. For the Syngas alternative, this is the case with increased $\mathrm{CO}_{2}$ quota prices. Bioethanol, on the other hand, results in a small decrease in $\mathrm{CO}_{2}$ emissions with increased fuel prices, although at a very high reduction cost. The Incineration, Biogas+ and Biodiesel alternatives are relatively insensitive to changes in the fuel prices, $\mathrm{CO}_{2}$ quota prices and investment rate. 


\section{Conclusion and discussion}

The analyses show that biogas and syngas plants are interesting alternatives to waste incineration. In today's energy system, the utilisation of organic waste in manure-based biogas production provides a negative $\mathrm{CO}_{2}$ reduction cost; i.e. it is a cheaper solution than today's incineration and it provides a $\mathrm{CO}_{2}$ reduction. It seems less important if the biogas is used for transport or $\mathrm{CHP}$. Using the biogas for transport provides the largest $\mathrm{CO}_{2}$ reduction while biogas for $\mathrm{CHP}$ gives the lowest $\mathrm{CO}_{2}$ reduction cost. However, if anaerobic digestion of waste does not facilitate the use of manure, the results change and the biogas plants have increased $\mathrm{CO}_{2}$ emissions. In a future $100 \%$ renewable energy system, biogas production is also a feasible solution providing the cheapest biomass reduction costs even without manure. The results concerning biogas are supported by the conclusions of other studies. Other studies show that biogas may be as good a solution as incineration or even a better alternative, depending on the concrete design of the system. It is here concluded that, in today's energy system, biogas production reduces $\mathrm{CO}_{2}$ emissions only if this production also leads to an increased anaerobic digestion of manure.

Syngas plants provide the lowest $\mathrm{CO}_{2}$ reduction cost in today's energy system, when it is assumed that co-gasification with coal is not necessary. If the waste is cogasified with coal, total $\mathrm{CO}_{2}$ emissions increase. Currently, plants which co-gasify waste with other resources are, however, only at the developmental stage and gasification of waste alone is even further from becoming a commercial technology. In a 100\% renewable energy future, Syngas with gasification of only waste provides a biomass reduction cost only slightly higher than incineration and still lower than the expected biomass cost. This alternative can also represent co-gasification of waste with biomass, in which waste replaces biomass in an existing biomass gasification plant.

If focusing only on $\mathrm{CO}_{2}$ emissions related to domestic electricity consumption, the Syngas+ alternative provides the largest $\mathrm{CO}_{2}$ reduction. This large difference in results illustrates the significance of determining the marginal electricity producing plant correctly.

If the current full resource potential is used, the BiogasTransport+ solution alone may contribute with a $\mathrm{CO}_{2}$ reduction of $3.1 \mathrm{Mt} /$ year and the Syngas with $0.9 \mathrm{Mt} /$ year. Even higher $\mathrm{CO}_{2}$ reductions may be achieved by combining several technologies, as they do to some extent utilise different waste fractions. Furthermore, a significant reduction in other greenhouse gases occurs due to reduced emissions of methane and nitrous oxide when spreading treated manure instead of raw. This factor is not included in the analysis, as it is not part of the energy conversion stage. If included, this factor will only support the conclusion of prioritising manure-based biogas production.

The conclusions are mainly sensitive to changes in waste resource prices, investment costs and efficiencies. There is in particular uncertainty about the waste resources, which do not have a well developed market. High sensitivity is found for the Incineration and Syngas alternatives and low for BiogasTransport+. The largest uncertainty about investment costs and 
efficiencies is related to the technologies which are yet at the development stage, such as Syngas and Bioethanol.

In general, a recommendation to decision-makers could be to support investments in utilisation of sorted organic household waste for biogas production today if this facilitates anaerobic digestion of manure. In the future biogas based on sorted organic household waste also appears to be a cheap way of saving biomass. Investments in infrastructure etc. facilitating this technology therefore appears to be beneficial also in the future. For paper and plastic a feasible option may in the short run be to co-combust in existing coal fired plants or in dedicated RDF plants. For the longer run it can be recommended to support research into gasification of both organic waste, paper and plastic without addition of coal or biomass. The remaining incinerable waste fractions should be incinerated in increasingly efficient and flexible waste incineration plants.

The study shows that there is potential in using waste for the production of transport fuels from an energy system perspective. Unless the processes facilitate anaerobic digestion of manure or gasification of waste alone (which is a technology that still has to be developed) it is, however, an expensive solution compared to current incineration. If the technologies are compared to other technologies producing biofuels they may, however, prove superior both from an environmental and economic perspective.

The second best solution seems to be to improve the electric efficiency and the flexibility of the energy system through sorting out RDF and cocombusting it with coal or burning it in a dedicated RDF plant. The combustion of coal in existing large-scale power plants must, however, take place in order for Co-combustion to be a feasible alternative. It is doubtful whether more coal-fired power plants will be built in the quest for a $100 \%$ renewable energy future and Co-combustion should therefore be regarded a short-term initiative, e.g. to overcome the lack of incineration capacity. When considering the investment in new plants, dedicated RDF plants provide a higher $\mathrm{CO}_{2}$ reduction and a lower $\mathrm{CO}_{2}$ reduction cost than new incineration. They can, however, only handle $19 \%$ of the waste which is currently incinerated.

As a significant fraction of mixed waste will still be left no matter which alternative is chosen, waste incineration will still be part of the solution when converting waste to energy in the future. Today, the Incineration alternative is an expensive solution in terms of reduced $\mathrm{CO}_{2}$, but it represents the replacement of existing waste incineration plants only with the aim of improving efficiency. If the plants are replaced when needed due to age or lack of capacity, the solution will not be nearly as expensive. In a $100 \%$ renewable energy future, waste incineration appears to be marginally cheaper in terms of biomass reduction than the Co-combustion and RDF alternatives.

Energy system analysis with hour-by-hour representation of demands and production takes the flexibility of the various technologies into account. Thus, it improves the results of the technologies which increase the flexibility compared to the current system, partly in terms of changed income from electricity trade, but also in terms of changed fuel consumption and reduced $\mathrm{CO}_{2}$ emissions. To assess whether the conclusions are also valid from a 
broader environmental perspective, the results regarding fuel substitution can be used for detailed life cycle assessment.

The energy system analysis in this study has included electricity trade with neighbouring countries, market economic optimisation, seven different technologies and analysis of a future scenarion with 100\% renewable energy. Furthermore, the model has been improved with regards to representation of a Syngas plant with production of both electricity, heat and biofuel for transportation. During the new analyses manure based biogas remains on of the preferable solutions. Syngas for transport also comes out as a feasible solution, however only when co-firing with coal is not undertaken. In the short term the Co-Combustion and RDF alternatives has also proven interesting.

As Denmark is one of the countries in the world with the highest wind power share in the electricity production, one of the highest shares of CHP as well as one of the highest shares of waste incineration it is an interesting case to analyse. Many countries are moving in the direction of Denmark with regards to wind and district heating and considering how to treat their waste in the future. They can learn from analyses of Denmark with regards to e.g. which challenges their energy system may face. In countries with little heat demand or little coverage with district heating, the WtE technologies which produce transport fuel or high degrees of electricity will be the most feasible.

\section{Acknowledgements}

Thanks are extended to Thilde Fruergaard from the Technical University of Denmark as well as the staff from Swedish Gas Centre, Waste Centre Denmark, DONG Energy, Danish Energy Authority, DAKA, Lemvig Biogas Plant and PlanEnergi for contributing with data to the analysis.

Furthermore, thanks are extended to Poul Erik Morthorst and Kenneth Karlsson from Risø National Laboratory, Brian Vad Mathiesen from Aalborg University, Thomas Astrup from the Technical University of Denmark, as well as Tore Hulgaard from Rambøll for valuable and inspiring discussions and comments on the paper.

Finally, thanks are extended to the anonymous reviewers for their valuable comments to the article.

The paper was partially funded by the Danish Research Agency's programme for strategic funding within sustainable energy administered by the Danish Technical Research Council (STVF) and is a part of the research project "ENSUWE - Environmentally Sustainable Utilization of Waste resources for Energy production". 


\section{References}

Baky, A. \& Eriksson, 0. Systems Analysis of Organic Waste Management in Denmark. Environmental Project no. 822, 2003. 2003. Danish Environmental Agency, Copenhagen

Borjeson, L., Hojer, M., Dreborg, K. H., Ekvall, T., \& Finnveden, G. 2006, Scenario types and techniques: Towards a user's guide, Futures, vol. 38, no. 7, pp. 723-739.

Bregnbaek, L. Future electricity prices. 10-10-2008. Ea Energianalyse a/s. Frederiksholms Kanal 1, 1. DK-1220 Copenhagen K

Cherubini, F., Bargigli, S., \& Ulgiati, S. 2008, Life cycle assessment of urban waste management: Energy performances and environmental impacts. The case of Rome, Italy, Waste Management, vol. 28, no. 12, pp. 2552-2564.

Commission Of The European Communities. Proposal for a Directive of the European Parliament and of the Council on the promotion of the use of energy from renewable sources. COM(2008) 19 final. 23-1-2008.

Cosmi, C., Cuomo, V., Macchiato, M., Mangiamele, L., Masi, S., \& Salvia, M. 2000, Waste management modeling by MARKAL model: A case study for Basilicata Region, Environmental Modeling \& Assessment, vol. 5, no. 1, pp. 19-27.

Council Of The European Union. Council Directive 1999/31/EC of 26 April 1999 on the landfill of waste. 16-7-1999. Official Journal L $182,0001-0019$

Danish Energy Authority 2007, Energy Statistics 2006. Danish Energy Authority, Copenhagen

Danish Energy Authority 2008a, Assumptions for socioeconomic analysis in the field of energy. Danish Energy Authority, Copenhagen

Danish Energy Authority 2008b, Basisfremskrivning af Danmarks Energiforbrug frem til 2025 (Forecast of the Danish Energy Supply until 2025). Danish Energy Authority, Copenhagen, Denmark

Dijkgraaf, E. \& Vollebergh, H. R. J. 2004, Burn or bury? A social cost comparison of final waste disposal methods, Ecological Economics, vol. 50, no. 3-4, pp. 233-247.

Dyrelund, A., Lund, H., Möller, B., Mathiesen, B. V., Fafner, K., Knudsen, S., Lykkemark, B., Ulbjerg, F., Laustsen, T. H., Larsen, J. M., \& Holm, P. 2008, Heatplan Denmark (In Danish Varmeplan Danmark) Project 2008 - 01. Danish District Heating Association, Kolding, Denmark

EA Energy Analysis 2008, Heatplan Copenhagen - Memo on assumptions regarding longterm fuel prices and CO2 prices (In Danish Notat om 
forudsætninger for de langsigtede brændselspriser og CO2 priser). EA Energy Analysis, Copenhagen, Denmark

Ekvall, T. 1999, Key methodological issues for life cycle inventory analysis of paper recycling, Journal of Cleaner Production, vol. 7, no. 4, pp. 281-294.

Energinet.dk. Udtræk af markedsdata - Systempriser 2006 (Extraction of market data - System prices 2006). 2008. Energinet.dk, Skaerbaek, Denmark

Eriksson, O., Finnveden, G., Ekvall, T., \& Bjorklund, A. 2007, Life cycle assessment of fuels for district heating: A comparison of waste incineration, biomass- and natural gas combustion, Energy Policy, vol. 35, no. 2, pp. 13461362.

Eshet, T., Ayalon, 0., \& Shechter, M. 2005, A critical review of economic valuation studies of externalities from incineration and landfilling, Waste Management \& Research, vol. 23, no. 6, pp. 487-504.

EUCAR, CONCAWE, \& Joint Research Centre of the EU Commission. Well-ToWheels Analysis Of Future Automotive Fuels And Powertrains In The European Context - WELL-to-WHEELS Report Version 2c. 2007. Joint Research Centre of the EU Commission,

European Commission. Taking sustainable use of resources forward: A Thematic Strategy on the prevention and recycling of waste. 21-12-2005. Brussels

Fatta, D. \& Moll, S. 2003, Assessment of information related to waste and material flows - A catalogues of methods and tools 96. EEA, Copenhagen, Denmark

Finnveden, G., Bjorklund, A., Moberg, A., Ekvall, T., \& Moberg, A. 2007a, Environmental and economic assessment methods for waste management decision-support: possibilities and limitations, Waste Management \& Research, vol. 25, no. 3, pp. 263-269.

Finnveden, G., Bjorklund, A., Reich, M. C., Eriksson, O., \& Sorbom, A. 2007b, Flexible and robust strategies for waste management in Sweden, Waste Management, vol. 27, no. 8, p. S1-S8.

Finnveden, G. 1999, Methodological aspects of life cycle assessment of integrated solid waste management systems, Resources, Conservation and Recycling, vol. 26, no. 3-4, pp. 173-187.

Fruergaard, T. 2008, Assessment of waste resources for energy production Fractions, quantities, segregation potentials and energy content. Danish Technical University, Department of Environmental Engineering, Lyngby, DK

Goudriaan, B., van de Beld, B., Boerefijn, F. R., Bos, G. M., Naber, J. E., van der Wal, S., \& Zeevalkink, J. A. Thermal Efficiency of the HTU Process for Biomass 
Liquefaction, in Progress in Thermochemical Biomass Conversion, Tyrol, Austria, A. V. Bridgwater, ed., pp. 1312-1325.

Holmgren, K. \& Henning, D. 2004, Comparison between material and energy recovery of municipal waste from an energy perspective - A study of two Swedish municipalities, Resources Conservation and Recycling, vol. 43, no. 1, pp. 51-73.

Hulgaard, T. Decrease in efficiency of waste incineration plants with cocombustion. 21-3-2009.

Kirkeby, J. T., Birgisdottir, H., Hansen, T. L., Christensen, T. H., Bhander, G. S., \& Hauschild, M. 2006, Evaluation of environmental impacts from municipal solid waste management in the municipality of Aarhus, Denmark (EASEWASTE), Waste Management \& Research, vol. 24, no. 1, pp. 16-26.

Knutsson, D., Sahlin, J., Werner, S., Ekvall, T., \& Ahlgren, E. O. 2006, HEATSPOT--a simulation tool for national district heating analyses, Energy, vol. 31 , no. $2-3$, pp. 278-293.

Ljunggren Soderman, M. 2003, Recovering energy from waste in Sweden--a systems engineering study, Resources, Conservation and Recycling, vol. 38, no. 2, pp. 89-121.

Lund, H. EnergyPLAN, Advanced Energy System Analysis Computer Model version, Documentation version 7.0. 2007a. Aalborg University, Aalborg

Lund, H. \& Lempton, W. 2008, Integration of renewable energy into the transport and electricity sectors through V2G, Energy Policy, vol. 36, no. 9, pp. 3578-3587.

Lund, H. \& Mathiesen, B. V. 2008, Energy system analysis of $100 \%$ renewable energy systems : the case of Denmark in years 2030 and 2050, Energy.

Lund, H. \& Munster, E. 2006, Integrated energy systems and local energy markets, Energy Policy, vol. 34, no. 10, pp. 1152-1160.

Lund, H. \& Münster, E. 2003, Modelling of energy systems with a high percentage of CHP and wind power, Renewable Energy, vol. 28, no. 14, pp. 2179-2193.

Lund, H., Salgi, G., Elmegaard, B., \& Andersen, A. N. 2009, Optimal operation strategies of compressed air energy storage (CAES) on electricity spot markets with fluctuating prices, Applied Thermal Engineering, vol. 29, no. 56, pp. 799-806.

Lund, H. 2007b, Renewable energy strategies for sustainable development, Energy, vol. 32, no. 6, pp. 912-919. 
Lund, H., Duic, N., ic, G., \& Grata Carvalho, M. d. 2007, Two energy system analysis models: A comparison of methodologies and results, Energy, vol. 32, no. 6, pp. 948-954.

Luoranen, M. \& Horttanainen, M. 2008, Co-generation based energy recovery from municipal solid waste integrated with the existing energy supply system, Waste Management, vol. 28, no. 1, pp. 30-38.

Mathiesen, B. V. 2008, Fuel Cells and Electrolysers in Future Energy Systems, Aalborg University.

Møller, J., Fruergaard, T., Riber, C., Astrup, T., \& Christensen, T. H. 2008, Environmental Assessment of Waste Incineration and Alternatives (In Danish). DTU Environment, Lyngby, Denmark

Morrissey, A. J. \& Browne, J. 2004, Waste management models and their application to sustainable waste management, Waste Management, vol. 24, no. 3, pp. 297-308.

Moutavtchi, V., Stenis, J., Hogland, W., Shepeleva, A., \& Andersson, H. 2008, Application of the WAMED model to landfilling, Journal of Material Cycles and Waste Management, vol. 10, no. 1, pp. 62-70.

Münster, M. 2008, Energy Systems Analysis of Waste-to-Energy Technologies using EnergyPLAN R1667(EN). Risoe DTU, Risoe, Denmark

Münster, M. \& Lund, H. Use of waste for heat, electricity and transport-Challenges when performing energy system analysis. 2008. Energy In Press, Corrected Proof

Nexant, I. Final Report Environmental Footprints and Costs of Coal-Based Integrated Gasification Combined Cycle and Pulverized Coal Technologies . 2006. EPA-430/R-06/006. U.S. Environmental Protection Agency Office of Air and Radiation,

Sahlin, J., Knutsson, D., \& Ekvall, T. 2004, Effects of planned expansion of waste incineration in the Swedish district heating systems, Resources, Conservation and Recycling, vol. 41, no. 4, pp. 279-292.

Salvia, M., Cosmi, C., Macchiato, M., \& Mangiamele, L. 2002, Waste management system optimisation for Southern Italy with MARKAL model, Resources, Conservation and Recycling, vol. 34, no. 2, pp. 91-106. 


\section{Appendix A - Mathematical representation of Syngas Module in EnergyPLAN}

The model is operated with market economic regulation, which is based on the principle that if the marginal production cost of producing electricity is lower than the market price (in competition with all the other units) the Syngas plant will produce the maximum amount of electricity possible otherwise it will produce the maximum amount of biofuel for transportation.

Input

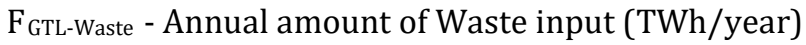

$\mathrm{F}_{\text {GTL-Coal }}$ - Annual amount of Coal input (TWh/year)

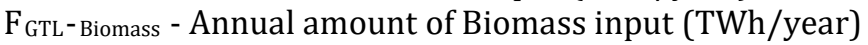

$\mathrm{f}_{\mathrm{GTL}}$-Biofuel - Annual production of biofuel (TWh/year)

- $\quad \mu_{\mathrm{GTL}-\mathrm{M} 1}$ - Electric output module 1

- $\quad \rho_{\text {GTL-M1 }}$ - Thermal output module 1

- $\quad \eta_{\text {GTL-M1 }}$ - Biofuel output module 1

- $\quad \mu_{\mathrm{GTL}-\mathrm{M} 2}$ - Electric output module 2

- $\quad$ GGTL-M2 - Thermal output module 2

- $\quad \eta_{\text {GTL-M2 }}$ - Biofuel output module 2

PVoc-GTL-M1 - Variable operation costs in module 1 (DKK/MWh fuel)

PVoc-GTL-M2 - Variable operation costs in module 2 (DKK/MWh fuel)

P UnIT-GTL - Investment pr. Unit (Mio.DKK/TWh fuel)

$\mathrm{n}_{\mathrm{GTL}}$ - Lifetime of Investment (Years)

$P_{\text {FoC-GTL }}$ - Fixed operation costs (\% of investment/year)

VOC - Variable operation costs (DKK/MWh)

Output:

- $\Delta \mathrm{q}_{\mathrm{GTL}}-$ Change in heat production (MWh)

- $\Delta \mathrm{e}_{\mathrm{GTL}}-$ Change in electricity production $(\mathrm{MWh})$

MC - Marginal costs (DKK/MWh)

\section{Initial calculations}

The fuel input is defined by the annual amounts and the distribution of waste input. All three fuel inputs (coal, biomass and waste) are following the same distribution.

$$
\mathrm{F}_{\mathrm{GTL}} \text {-Total }=\mathrm{F}_{\mathrm{GTL}-\text { Waste }}+\mathrm{F}_{\text {GTL-Coal }}+\mathrm{F}_{\text {GTL-Biomass }}
$$

The hourly fuel input ( $\mathrm{F}_{\mathrm{GTL}}$-Total $)$ is found by using the hourly distribution of waste ( $\left.\delta_{\text {Waste }}\right)$ specified in the waste input tab sheet. 


$$
\mathrm{f}_{\mathrm{GTL}-\mathrm{Total}}=\mathrm{F}_{\mathrm{GTL}-\text { Total }} * \delta_{\text {Waste }} / \Sigma \delta_{\text {Waste }}
$$

Based on such input the Syngas plant can choose between the modules of operation defined by the input efficiencies.

Heat is supplied to the district heating system of larger city areas

Biofuel is replacing fossil fuel (e.g. petrol) for transportation

Electricity is supplied to the public grid

Initially the plant is set to operate according to module 1

The marginal cost of increasing electricity production by operating the plant in module 2 instead of 1 is calculated in two situations. One in which the heat replace heat from the boiler (B3) and one in which it replaces heat from CHP3.

In both situations the change in variable operation costs $(\Delta V O C)$, the decrease in Biofuel

production $\left(\Delta \mathrm{f}_{\mathrm{GTL}}\right.$-Petrol $)$ and the cost of not producing Petrol $(\Delta \operatorname{CostPetrol})$ is:

$$
\begin{aligned}
& \triangle \mathrm{VOC}=(\mathrm{P} \text { voc-GTL-M2 }- \text { Pvoc-GTL-M1 }) \\
& \Delta \mathrm{f}_{\text {GTL-Petrol }}=\mathrm{F}_{\text {GTL-Total }} *\left(\eta_{\text {GTL-M1 }}-\eta_{\text {GTL-M2 }}\right) \\
& \Delta \operatorname{Cost}_{\text {Petrol }}=\Delta \mathrm{f}_{\mathrm{GTL}-\text { Petrol }} *\left(\mathrm{P}_{\text {Petrol-WM }}+\mathrm{CO} 2 \text { oil } * \mathrm{P}_{\text {c02-trade }}\right)
\end{aligned}
$$

In the case of replacing boiler heat production the saved costs are calculated as follows:

$$
\begin{gathered}
\Delta \mathrm{q}_{\mathrm{GTL}}=\mathrm{F}_{\mathrm{GTL}-\mathrm{Total}} *\left(\rho_{\mathrm{GTL}-\mathrm{M} 2}-\rho_{\mathrm{GTL}-\mathrm{M} 1}\right) \\
\Delta \mathrm{F}_{\mathrm{B} 3}=\Delta \mathrm{q}_{\mathrm{GTL}} / \rho_{\mathrm{B} 3} \\
\Delta \text { Cost }_{\text {Heat }}=\Delta \mathrm{F}_{\mathrm{B} 3} *\left(\mathrm{P}_{\text {Fuel-B3 }}+\mathrm{CO} 2{ }_{\mathrm{B} 3} * \mathrm{P}_{\text {CO2-trade }}\right)+\mathrm{VOC}_{\mathrm{B} 3} * \Delta \mathrm{q}_{\mathrm{GTL}}
\end{gathered}
$$

The increase in electricity production and the marginal costs are then found:

$$
\begin{gathered}
\Delta \mathrm{e}_{\mathrm{GTL}}=\mathrm{F}_{\text {GTL-Total }} *\left(\eta_{\mathrm{GTL}} \mathrm{M}_{2}-\eta_{\mathrm{GTL}-\mathrm{M} 1}\right) \\
\mathrm{MC}_{\text {IncGTLdecB3 }}=\left(\Delta \mathrm{VOC}+\Delta \text { Cost }_{\text {Petrol }}-\Delta \text { Cost }_{\text {Heat }}\right) / \Delta \mathrm{e}_{\mathrm{GTL}}
\end{gathered}
$$

In the case of replacing CHP3 heat production the saved costs are calculated as follows:

$$
\begin{gathered}
\Delta \mathrm{F}_{\text {CHP3 }}=\Delta \mathrm{q}_{\mathrm{GTL}} / \rho_{\text {СHP3 }} \\
\Delta \mathrm{e}_{\text {CHP3 }}=\Delta \mathrm{F}_{\mathrm{CHP} 3} * \eta_{\mathrm{CHP} 3} \\
\Delta \text { Cost }_{\text {Heat }}=\Delta \mathrm{F}_{\text {CHP3 }} * \mathrm{P}_{\text {Fuel-CHP3 } 3}+\operatorname{VOC}_{\text {CHP3 }} * \Delta \mathrm{e}_{\mathrm{CHP} 3}
\end{gathered}
$$

The increase in electricity production and the marginal costs are then found:

$$
\mathrm{MC}_{\text {IncGTLdecCHP3 }}=\left(\Delta \mathrm{VOC}+\Delta \text { Cost }_{\text {Petrol }}-\Delta \text { Cost }_{\text {Heat }}\right) /\left(\Delta \mathrm{e}_{\mathrm{GTL}}-\Delta \mathrm{e}_{\mathrm{CHP} 3}\right)
$$

